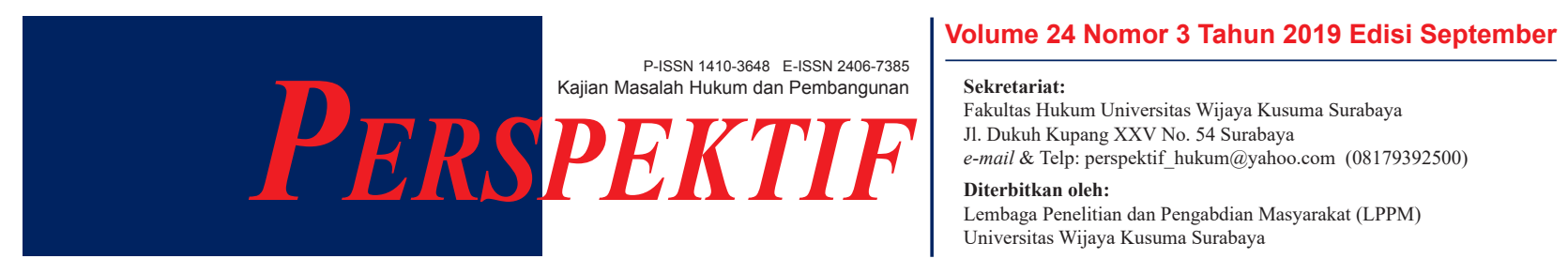

\title{
KEWENANGAN LEMBAGA HUKUM DALAM MENENTUKAN BESARAN KERUGIAN DAN PENGEMBALIAN KEUANGAN NEGARA HASIL TINDAK PIDANA KORUPSI
}

\author{
Novian Ardynata Setya Pradana \\ Magister Hukum, Fakultas Hukum, Universitas Airlangga \\ e-mail: ardynatasp1994@gmail.com \\ Arif Satria Subekti \\ Magister Hukum, Fakultas Hukum, Universitas Airlangga \\ e-mail: satriasubekti329@gmail.com \\ Cahyo Harjo Prakoso \\ Magister Hukum, Fakultas Hukum, Universitas Airlangga \\ e-mail: cahyoharjo@icloud.com
}

\begin{abstract}
ABSTRAK
Dalam memeriksa suatu perkara tindak pidana korupsi untuk menentukan suatu kerugian negara, maka kewenangan melakukan audit adalah BPK sesuai dengan Pasal 2 Undang-Undang Nomor 15 Tahun 2006 tentang Badan Pemeriksa Keuangan, kedudukan BPK merupakan Badan Pemeriksa Keuangan yang paling tinggi dalam hal keuangan negara, yang diatur dalam Pasal 23 ayat (5) Undang-Undang Dasar 1945. Tetapi pada kenyataannya Jaksa melakukan kewenangan penyidikan dalam perkara korupsi melebihi kewenangannya. Jaksa juga melakukan kewenangan melakukan audit kerugian keuangan negara, hal tersebut melebihi kewenangan Jaksa dan mengambil alih kewenangan BPK. Kondisi ini menyebabkan kerancuan siapa yang berhak untuk menghitung kerugian keuangan Negara dan mekanisme pengembalian kerugian keuangan negara dari tindak pidana korupsi. Metode pemecahan masalah menggunakan pendekatan normatif menggunakan peraturan per Undang-Undangan yang berlaku dan pendekatan konseptual diambil dari teori dan doktrin hukum yang sudah ada. Sesuai faktanya aturan Pasal 18 Undang-Undang Nomor 31 Tahun 1999 dengan PERMA Nomor 5 Tahun 2015 juga tidak ada proses mekanisme secara rinci pembayaran kerugian tetapi lebih menjelaskan mengenai perampasan penyitaan lalu dilelang guna menutupi kerugian negara Dengan ini perlu adanya aturan terkait mekanisme pengembalian dan kewenangan dalam menentukan jumlah kerugian negara.
\end{abstract}

Kata Kunci: Korupsi; BPK; Jaksa

\begin{abstract}
In examining certain cases of corruption to determine a state loss, the authority to audit is BPK in accordance with Article 2 of the BPK law. The position of the supreme audit board is the highest audit agency in the case of the finances state, as regulated in Article 23 paragraph 5 of the 1945 Constitution. However at reality the Prosecutor conducts investigative authority in corruption case, sometimes exceeding their authority. This condition causes confusion which intitution have authority to calculate financial state loss and mechanism for recovering financial state losses from corruption. The problem soving method uses a statue approach which it uses applicable regulation and law and conseptual approach from the theory and doctrine that still exist. Actually the fact from Article 18 Regulations number 31/1999 and PERMA number 5/2015 there is no rules of state financial loss return but it just explain of seizure adn foreclosure then auctioned off for compesate the financial loss. Because of that problem, the conclusion is to make a new regulation about mechanism recovering financial state losses and the authority of calculate financial state loss.
\end{abstract}

Keywords: Corruption; BPK; Prosecutor 
Novian Ardynata Setya Pradana, Arif Satria Subekti, dan Cahyo Harjo Prakoso,

Kewenangan Lembaga Hukum Dalam Menentukan Besaran Kerugian dan Pengembalian Keuangan Negara Hasil Tindak Pidana Korupsi

\section{PENDAHULUAN}

Korupsi adalah masalah yang sangat kompleks yang dihadapi oleh seluruh negara di dunia, permasalahan korupsi tersebut adalah permasalahan yang dimulai dari moral, etika dan kewajiban dari seseorang atau kelompok orang. Pengertian korupsi di Indonesa menurut para ahli hukum terdahulu diantaranya Helbert Edelherz yang menggunakan istilah white collar crime untuk perbuatan tindak pidana korupsi. ${ }^{1}$ Kemudian menurut Poerwadarminta korupsi adalah suatu perbuatan melawan hukum atau perbuatan yang tidak sepatutnya terbilang buruk seperti penggelapan uang, penerimaan uang yang ditempatkan pada suatu perusahaan atau lain sebagainya". ${ }^{2}$ Dari kedua pendapat tersebut penulis berpendapat bahwa tindak pidana korupsi adalah perbuatan yang didasari atas hancurnya moral dan etika seseorang yang disengaja agar menguntungkan diri sendiri ataupun orang lain yaitu teman atau kerabat yang dekat dengan dia dan menimbulkan kerugian keuangan negara. Penyalahgunaan kewenangan, menggunakan kesempatan, sarana yang ada padanya kedudukan dan jabatan dipandang sebagai unsur yang bersifat alternatif, hal tersebut terdapat pada Putusan Mahkamah Agung RI No. $934 \mathrm{~K} / \mathrm{Pid} / 1999$ tanggal 28 Agustus 2000 yang menyatakan bahwa suatu unsur penyalahgunaan wewenang adalah menyalahgunakan kesempatan, menyalahgunakan sarana merupakan unsur yang berdiri sendiri atau sifatnya alternatif. ${ }^{3}$

Bila dikaitkan dengan sejarah maka korupsi tersebut sudah dilakukan sejak dulu hingga kini, sebuah permasalahan yang sangat kompleks hingga penulis berpendapat hal tersebut menjadi culture atau adat di Indonesia. Bilamana korupsi dikaitkan dengan ilmu ekonomi maka korupsi yang berkaitan dengan keuangan negara berkaitan dengan besaran-besaran dalam ilmu ekonomi makro seperti pendapatan nasional, investasi masyarakat, konsumsi masyarakat, multiplier, acceleration principle dan lain-lain. ${ }^{4}$

\footnotetext{
${ }^{1}$ Ermansjah Djaja. (2008). Memberantas Korupsi Bersama KPK. Jakarta: Sinar Grafika, h. 7.

${ }^{2}$ W.J.S Poerwadarminta. (1976). Kamus Umum Bahasa Indonesia. Jakarta: Balai Pustaka, h. 524.

3 Nur Basuki Minarno. (2007). "Pembuktian Unsur Penyalahgunaan Wewenang Dalam Tindak Pidana Korupsi". Jurnal Perspektif.12(1), h. 54-55.

${ }^{4}$ Soetrisno. (1982). Dasar Dasar Ilmu Keuangan Negara. Yogyakarta: Fakultas Ekonomi Universitas Gadjah Mada, h.3.
}

Pada dasarnya tindak pidana korupsi keberadaanya sudah terdapat dalam hukum positif Indonesia yaitu di dalam Kitab Undang-Undang Hukum Pidana, sebelumnya tindak pidana korupsi telah tercantum dalam Peraturan Penguasa Militer No. PRT/PM/06/1957 tentang Pemberantasan Korupsi tetapi hanya berlakunya semetara dikarenakan pemerintah telah mempersiapkan peraturan perundang-undangan yang dapat menggantikan Peraturan Penguasaan Militer tersebut. Rumusan dan batasan tentang tindak pidana korupsi yang di atur dalam Peraturan Penguasa Militer Nomor. PRT/PM06/1957 dapat dikelompokkan menjadi dua, yaitu: ${ }^{5}$

1. Setiap perbuatan yang dilakukan oleh siapapun yang berkaitan dengan kepentingan diri sendiri, untuk kepentingan orang terdekat, atau untuk kepentingan suatu badan yang langsung ataupun tidak langsung yang dapat memberikan dampak kerugian keuangan negara;

2. Tiap perbuatan yang dilakukan oleh seorang pejabat yang mmenerima gaji atau upah dari suatu badan yang menerima bantuan dari keuangan negara atau daerah, dengan mempergunakan kewenangan atau kekuasaan yang oleh jabatan langsung atau tidak langsung memberikan keuntungan baginya.

Tetapi perumusan subyek pelaku dalam Kitab Undang-Undang Hukum Pidana (KUHP) tidak mengenal korporasi sebagai pelaku. Secara konvensional pelaku tindak pidana korupsi yang ada di dalam KUHP hanya mengenal orang. Korporasi sebagai subyek hukum tindak pidana korupsi baru ditetapkan oleh Pasal 1 angka 3 Undang-Undang No. 31 Tahun 1999, masuk dalam kategori "setiap orang". Dengan demikian maka konsekuensinya korporasi dapat dituntut pertanggungjawaban dan dapat pula dijatuhi pidana.

Korporasi sebagai subjek hukum tindak pidana korupsi ditetapkan oleh Pasal 1 angka 3 UndangUndang Nomor 31 Tahun 1999 jo. Undang-Undang Nomor 20 Tahun 2001 Tentang Pemberantasan Tindak Pidana Korupsi (termasuk "setiap orang") sehingga konsekuensinya korporasi dapat dituntut pertanggungjawaban dan dapat dijatuhkan pidana. Dalam hal tindak pidana korupsi dilakukan oleh atau atas nama suatu korporasi, maka tuntutan

\footnotetext{
${ }^{5}$ Ermansjah Djaja, op.cit., h. 11.
} 
dan penjatuhan pidana dapat dilakukan terhadap korporasi dan atau pengurusnya. Pidana pokok yang dapat dijatuhkan terhadap korporasi hanya pidana denda, dengan ketentuan maksimum pidana ditambah $1 / 3$ (satu pertiga). Selain itu korporasi juga dapat dikenakan pidana tambahan yaitu:

a. Perampasan barang bergerak yang berwujud atau yang tidak berwujud atau barang tidak bergerak yang digunakan untuk atau yang diperoleh dari tindak pidana korupsi, termasuk perusahaan milik terpidana di mana tindak pidana korupsi dilakukan, begitu pula dari barang yang menggantikan barang-barang tersebut;

b. Pembayaran uang pengganti yang jumlahnya sebanyak-banyaknya sama dengan harta benda yang diperoleh dari tindak pidana korupsi;

c. Penutupan seluruh atau sebagian perusahaan untuk waktu paling lama 1 (satu) tahun;

d. Pencabutan seluruh atau sebagian hak-hak tertentu atau penghapusan seluruh atau sebagian keuntungan tertentu, yang telah atau dapat diberikan oleh Pemerintah kepada terpidana.

Jika terpidana (korporasi) tidak membayar uang pengganti paling lama dalam waktu 1 (satu) bulan sesudah putusan pengadilan yang telah memperoleh kekuatan hukum tetap, maka harta bendanya dapat disita oleh Jaksa dan dilelang untuk menutupi uang pengganti tersebut.

Sesuai Pasal 9 ayat (3) Peraturan Mahkamah Agung Nomor 5 Tahun 2014 tentang Pidana Tambahan Uang Pengganti Dalam Tindak Pidana Korupsi, pelaksanaan lelang dilakukan selambatlambatnya 3 (tiga) bulan setelah dilakukan penyitaan. ${ }^{6}$ Selain itu dapat juga dipertimbangan penghukuman oleh hakim bahwa bilamana tidak juga dianggap cukup menjerakan melalui pengenaan pidana pembayaran uang pengganti maka bisa dijatuhkan pula pidana tambahan berupa penutupan usaha korporasi selamanya ataupun dalam waktu yang sementara. ${ }^{?}$

Pada praktiknya, belum terdapat kesamaan pandangan mengenai parameter penentuan besaran

${ }^{6}$ Pasal 9 ayat (3) Peraturan Mahkamah Agung Nomor 5 Tahun 2014 tentang Pidana Tambahan Uang Pengganti Dalam Tindak Pidana Korupsi.

${ }^{7}$ Budi Hariyanto. (2018). "Penerapan Pidana Uang pengganti Kepada Korporasi Dalam Perkara Korupsi Demi Pemulihan Kerugian Keuangan Negara". Jurnal RECHTSVINDING Media Pembinaan Hukum Nasional. Volume 7 Nomor 1 Tahun 2018. uang pengganti dimana dalam beberapa kondisi sering dihitung berdasarkan jumlah kerugian Negara yang ditimbulkan, namun pada kondisi lain dihitung berdasarkan jumlah harta benda yang diperoleh dari tindak pidana korupsi tersebut. Untuk menjawab permasalahan tersebut, diperlukan adanya suatu pengaturan yang jelas mengenai parameter perhitungan besaran uang pengganti. Sesuai dengan Pasal 18 ayat (1) Undang-Undang Nomor 31 Tahun 1999 yang pada intinya mengatakan bahwa besaran jumlah uang pengganti didasarkan dari besaran harta benda terpidana yang diperoleh dari tindak pidana korupsi. Oleh karenanya Mahkamah Agung melalui Peraturan Mahkamah Agung Nomor 5 Tahun 2014 tentang Pidana Tambahan Uang Pengganti dalam Tindak Pidana Korupsi menegaskan bahwa parameter perhitungan besaran uang pengganti adalah sebanyak-banyaknya sama dengan harta benda yang diperoleh dari tindak pidana korupsi. Dengan demikian, pemahaman bahwa parameter perhitungan besaran uang pengganti ditinjau dari besaran kerugian Negara sudah tidak dapat diterapkan dalam suatu persidangan tindak pidana korupsi. ${ }^{8}$

Selain masalah besaran uang pengganti, persoalan lain yang juga menimbulkan polemik adalah berkaitan dengan dijatuhinya pidana uang pengganti kepada korporasi yang tidak dijadikan Terdakwa. Dalam Pasal 17 Undang-Undang Nomor 31 Tahun 1999 dinyatakan bahwa selain dijatuhi pidana pokok, Terdakwa dapat dijatuhi pidana tambahan sebagaimana dimaksud dalam Pasal 18. Berdasarkan ketentuan tersebut maka pidana tambahan berupa pembayaran uang pengganti hanya dapat dijatuhkan kepada Terdakwa.

Namun dalam perkembangannya tak jarang Jaksa Penuntut Umum memasukkan tuntutan pembayaran uang pengganti juga kepada pihak ketiga (dalam hal ini termasuk korporasi). Tuntutan yang demikian selain tidak memiliki dasar hukum, pada prinsipnya juga melanggar prinsip-prinsip peradilan yang fair (fair trial), oleh karena pihak ketiga tersebut dikenakan tuntutan tanpa pernah diberikan kesempatan untuk melakukan pembelaan diri layaknya Terdakwa dalam persidangan yang terbuka untuk umum.

\footnotetext{
${ }^{8}$ Penjelasan Umum Peraturan Mahkamah Agung Nomor 5 Tahun 2014 tentang Pidana Tambahan Uang Pengganti Dalam Tindak Pidana Korupsi.
} 
Novian Ardynata Setya Pradana, Arif Satria Subekti, dan Cahyo Harjo Prakoso,

Kewenangan Lembaga Hukum Dalam Menentukan Besaran Kerugian dan Pengembalian Keuangan Negara Hasil Tindak Pidana Korupsi

Tindak pidana korupsi merupakan tindak pidana yang merugikan negara dengan cara merampas aset yang seharusnya menjadi hak negara hilang karena penyalah gunaan kekuasaan atau jabatan yang dimiliki seseorang. Aset yang dirampas seharusnya merupakan hak dari negara yang akan dipergunakan untuk mensejahterakan dan memenuhi keinginan daripada masyarakat, jika pejabat/pegawai negeri mempergunakan kewenangan dan kekuasaan yang dimilikinya secara salah dan melawan hukum guna menguntungkan diri sendiri atau orang lain dengan tujuan dan maksud tertentu maka dengan begitu kepentingan atau hak aset dari negara tersebut hilang dengan adanya korupsi yang dilakukan oleh pejabat tersebut. Pejabat disini berupa pejabat pegawai negeri yang mana dalam KUHP dijelaskan pada Pasal 92 ayat (1) menjelaskan pengertian pejabat itu sendiri. Pegawai negeri itu memiliki arti menurut Hoge Raad dalam P.A.F Lamintang dan Theo Lamintang ialah orang yang di angkat oleh kekuasaan umum dalam suatu pekerjaan yang bersifat umum, untuk melaksanakan sebagian dari tugas negara atau dari alat-alat perlengkapannya. Pegawai negeri bukan hanya orang yang pada pekerjaannya oleh undangundang telah dikaitkan dengan pangkat seorang pegawai negeri. ${ }^{9}$

Adanya perampasan aset oleh oknum yang menyalahgunakan kewenangan atau kekuasaannya guna memperkaya diri sendiri atau orang yang telah berjasa dan dianggap dekat, maka timbul kerugian negara karena yang seharusnya hak negara dapat disalurkan oleh pemerintah untuk program pembangunan serta mensejahterakan masyarakat telah diambil oleh pejabat negara yang tidak bertanggung jawab atau dapat dikatakan sebagai koruptor. Oleh karena itu negara berhak mendapatkan kembali apa yang menjadi hak negara tersebut. Proses audit dilakukan oleh lembaga yang berwenang sebagai auditor atas timbulnya kerugian keuangan negara yaitu BPK, BPKP dan Akuntan Publik, pernyataan tersebut terdapat dalam Undang-Undang Nomor 15 Tahun 2006 tentang BPK.

Pada pasal 18 ayat (1) huruf b Undang-Undang Nomor 31 tahun 1999 jo. Undang-undang Nomor 20 Tahun 2010 tentang Pemberantasan Tipikor

\footnotetext{
${ }^{9}$ P.A.F Lamintang dan Theo Lamintang. (2009). Delik-Delik Khusus Kejahatan Jabatan dan Kejahatan Jabatan Tertentu Sebagai Tindak Pidana Korupsi. Jakarta: Sinar Grafika, h. 12.
}

menerangkan secara tidak pasti penghitungan jumlah kerugian negara yang timbul karena hasil tindak pidana korupsi tersebut maksimal harus terpenuhi berapa persen dari jumlah total dari hasil tindak pidana korupsi atau minimal berapa persen dari hasil tindak pidana, penentuan pembayaran uang pengganti kerugian keuangan negara hanya di tentukan oleh Jaksa Penuntut Umum dan juga Hakim.

Sebagai contoh adanya kasus yang telah diputus oleh Putusan Mahkamah Agung RI dengan No. 682 K/PID/2004 tanggal 28 Nopember 2005 juncto Putusan Pengadilan Tinggi DKI Jakarta No. 133/ PID/2003/PT.DKI tanggal 29 Desember 2003 juncto Putusan Pengadilan Negeri Jakarta Pusat No. 1667/ PID.B/2002/PN.JKT.PST tanggal 22 April 2003, H. Probosutedjo merugikan negara dengan hasil korupsi sebesar Rp. 100.931.585.000,- (seratus miliar sembilan ratus tiga puluh satu juta lima ratus delapan puluh lima ribu rupiah) dan dikenakan pidana denda yaitu sebesar Rp. 30.000.000,- (tiga puluh juta rupiah) dan hakim menetapkan agar H. Probosutedjo membayar uang pengganti kerugian negara sebanyakbanyaknya yaitu maksimal dari hasil kerugian negara yang sudah ada Rp. 100.931.585.000,- (seratus miliar sembilan ratus tiga puluh satu juta lima ratus delapan puluh lima ribu rupiah). Berbeda halnya dengan kasus Ir. HARIS FADILAH bin H. IMAM HAMBALI dengan putusan Mahkamah Agung No. $2471 \mathrm{~K} / \mathrm{Pid} / 2006$ Tanggal 15 Maret 2007 menyatakan Ir. HARIS FADILAH bin H. IMAM HAMBALI terbukti merugikan keuangan negara sebesar Rp. $556.111 .712,18$,- tetapi pidana tambahan pengganti kerugian keuangan negara hanya dibebankan sebesar Rp.512.394.819,-. Adanya celah dalam UndangUndang tersebut memberikan kesempatan para koruptor memainkan kembali uang hasil korupsinya untuk merubah atau mempengaruhi tuntutan maupun mempengaruhi putusan hakim. Penghitungan minimal dan maksimal akan memperjelas Pasal 18 ayat (1) huruf $b$ tersebut agar tidak ada celah yang dapat kembali dimainkan. Ini dapat diartikan bahwa Jaksa Penuntut Umum maupun Hakim telah memiliki acuan pedoman dalam melaksanakan tuntutannya dan putusannya, sehingga tidak ada proses tawar menawar kembali secara tersembunyi dan sistematis.

Secara nyata Majelis Permusyawaratan Rakyat mengamanatkan dalam TAP MPR-RI Nomor XI/ MPR/1989 tentang Penyelenggaraan Negara Yang 
Bersih dan Bebas KKN, lalu ditindaklanjuti dengan dikeluarkannya Undang-Undang Nomor 28 Tahun 1999 tentang Penyelenggaraan Negara yang Bersih dan Bebas dari Korupsi, Kolusi dan Nepotisme.

Kedudukan Badan Pengawas Keuangan dan Pembangunan (yang selanjutnya disebut BPKP) adalah suatu lembaga tidak termasuk dalam Departemen yang berada dibawah dan bertanggung jawab langsung kepada Presiden, BPKP lahir berdasarkan Keputusan Presiden Nomor 31 Tahun 1983. Jika kita menengok UUD 1945, tidak ada pasal yang menyebutkan secara nyata tentang Badan tersebut. Akan tetapi Presiden selaku Kepala Pemerintahan mempunyai wewenang mengadakan suatu Badan dalam lingkungan Pemerintah/ eksekutif yang menurut pertimbangan Presiden perlu dipertimbangkan. ${ }^{10}$

Berbeda halnya dengan Penghitungan Kerugian Keuangan Negara berdasarkan Pasal 1 angka 1 Undang-undang Nomor 15 Tahun 2006 tentang Badan Pemeriksa Keuangan (yang selanjutnya disebut UU BPK) dijelaskan bahwa BPK, adalah lembaga Negara yang bertugas untuk memeiksa pengelolaan dan tanggung jawab keuangan negara sebagaimana dimaksud dalam Undang-Undang Dasar Negara Republik Indonesia Tahun 1945.” Kedudukan BPK merupakan Badan Pengawas yang tertinggi dalam hal pengawasan keuangan Negara, yang diatur dalam Pasal 23 ayat (5) UUD 1945. Kedudukan BPK ini dapat dilihat dalam penjelasan Pasal 23 ayat 5 UUD 1945 jo. Undang-undang No. 5 Tahun 1973 yang menyatakan bahwa BPK memeriksa tanggung jawab Pemerintah tentang keuangan Negara, yang pelaksanaan tugas tidak berpengaruh terhadap kekuasaan pemerintahan akan tetapi tidak berdiri diatas pemerintah. ${ }^{11}$

Jadi dalam hal ini KPK dapat berkoordinasi dengan Kepolisian dan Kejaksaan dan KPK dapat menjalankan tugasnya bersama instansi yang berwenang dalam pemberantasan tindak pidana korupsi seperti BPKP, BPK, dan Inspektorat Jenderal di Departemen dan Non-Departemen. Tetapi karena kondisi ini mengakibatkan timbulnya kerancuan siapakah yang sebenarnya berhak untuk menghitung kerugian keuangan negara, karena ada banyak

\footnotetext{
${ }^{10}$ Bohari. (1992). Pengawasan Keuangan Negara. Jakarta: Rajawali, h. 41.

11 ibid., h. 50.
}

undang-undang yang mengatur tentang kerugian keuangan negara.

\section{PERUMUSAN MASALAH}

Mekanisme dan kewenangan pengembalian kerugian keuangan negara hasil tindak pidana korupsi ditinjau dari peraturan tindak pidana korupsi.

\section{METODE PENELITIAN}

Penelitian ini merupakan penelitian normatif, dan menggunakan metode pendekatan statute approach (pendekatan perundang-undangan) dan conceptual approach (pendekatan konseptual). ${ }^{12}$

\section{PEMBAHASAN}

\section{Mekanisme Pengembalian Kerugian Keuangan Negara Hasil Tindak Pidana Korupsi Ditinjau Dari Peraturan Perundang-Undangan Tindak Pidana Korupsi}

Berdasarkan analisa terhadap ketentuanketentuan yang ada dalam Undang-Undang No. 20 Tahun 2001 jo Undang-Undang No. 31 Tahun 1999 maka tindak pidana korupsi dikategorikan menjadi dua, yaitu tindak pidana korupsi itu sendiri dan tindak pidana yang berkaitan dengan tindak pidana korupsi. Kategori pertama tersebut dapat ditemui dalam ketentuan Pasal 5 s/d 12 Undang-Undang No. 20 Tahun 2001 jo Pasal 13 s/d 16 Undang-Undang No. 31 Tahun 1999. Kategori kedua dapat dilihat dalam Pasal 21-24 Undang-Undang Nomor 31 Tahun 1999. Bila dilihat dari kategorisasi yang pertama maka untuk pelaku tindak pidana korupsi maupun yang memberi bantuan agar korupsi dapat berjalan lancar, dan kategorisasi yang kedua merupakan titik berat dari yang pertama yaitu:

1. Perbuatan mencegah, merintangi, atau menggagalkann secara langsungg penyidikan, penuntutann, dan pemeriksaan di sidang Pengadilan terhadapp tersangka. (Pasal 211);

2. Perbuatan menghalang-halangi atau tidak memberikan keterangan secara benar (Pasal 22);

3. Pelanggaran terhadap ketentuan dalam Pasal 220, Pasal 231, Pasal 421, Pasal 442, Pasal 429 atau Pasal 430 Kitab Undang-Undang Hukum Pidana (Pasal 23).

\footnotetext{
${ }^{12}$ Peter Mahmud Marzuki. (2005). Penelitian Hukum. Edisi Pertama. Cet. VII. Jakarta: Kencana, h. 93-94.
} 
Novian Ardynata Setya Pradana, Arif Satria Subekti, dan Cahyo Harjo Prakoso,

Kewenangan Lembaga Hukum Dalam Menentukan Besaran Kerugian dan Pengembalian Keuangan Negara Hasil Tindak Pidana Korupsi

Pidana tambahan mengenai pembayaran kerugian keuangan negara yang telah di atur dalam Pasal 18 ayat (1) huruf b Undang-Undang Nomor 31 Tahun 1999 jo. Pasal 1 Peraturan Mahkamah Agung Republik Indonesia Nomor 5 Tahun 2014 dinyatakan bahwa pidana tambahan pembayaran uang pengganti adalah sebanyak-banyaknya sama seperti apa yang telah diperoleh pelaku dari tindak pidana korupsi bukan hanya dari audit kerugian keuangan negara.

Bilamana terdakwa tidak dapat membayar uang pengganti yang ditetapkan oleh putusan pengadilan maka barang-barang yang telah disita oleh jaksa dapat dilelang sesuai dengan putusan yang telah ada penetapan waktu penyitaan setelah putusan adalah 1 bulan setelah putusan berkekuatan hukum tetap dan lalu dilelang (Pasal 18 ayat (2) Undang-Undang Nomor 31 Tahun 1999) jaksa wajib melelang harta benda pelaku tindak pidana korupsi tersebut dengan beracuan pada Pasal 273 ayat (3) KUHAP. Bilamana terpidana tidak dapat membayarkan uang pengganti dan harta bendanya setelah dilakukan perhitungan ternyataa tidak cukup untuk dilakukan perampasan atau pelelangan maka tindakan yang akan dikenakan yaitu pidana penjara pengganti yang lamanya tidak melebihi ancaman maksimum pidana pokoknya dan lamanya tersebut terdapat dalam putusan pengadilan, penjara pengganti yang harus dijalankan oleh terdakwa diperhitungkan oleh jaksa sesuai dengan pembayaran uang pengganti yang telah dibayarkan sebelum penjara pokoknya usai hal ini tercantum dalam Pasal 10 ayat (1) Peraturan MA Republik Indonesia Nomor 5 Tahun 2014 tentang Pidana Tambahan Uang Pengganti Dalam Tindak Pidana Korupsi.

Bila diperinci kembali pengembalian kerugian keuangan negara ini adalah pidana tambahan yang dijatuhkan melalui proses persidangan oleh Hakim disamping menjatuhkan pidana pokok juga menjatuhkan pidana tambahan. jika dilihat dalam ranah pidana tambahan dapat diberikan oleh Hakim yang dalam kapasitasnya berkolerasi dengan pengembalian aset dengan melalui prosedur pidana dapat berupa:

a. Perampasan yang dilakukan terhadap barang bergerak berwujud atau tidak berwujud digunakan untuk memperoleh aset-aset yang dapat dilakukan lelang dari tindak pidana korupsi termasuk perusahaan atau aset yang diperoleh dari tindak pidana korupsi (Pasal 18 ayat (1) huruf a Undang-Undang Nomor 31 Tahun 1999);

b. Pembayaran uang pengganti yang jumlahnya sebanyak-banyaknya sama dengan jumlah harta benda yang diperooleh dari tindak pidana korupsi. Jika terpidana tidak dapat membayar uang pengganti sebagaimana yang tertera dalam ayat (1) huruf b paling lama dalam waktu 1 (satu) bulan sesudah putusan yang telah memperoleh kekuatan hukum tetap, maka oleh karena itu harta bendanya dapat dilakukan penyitaan dan perampasan hingga nantinya akan dilelang oleh Jaksa. Dalam ayat (1) huruf b, maka dipidana dengan pidana penjara yang lamanya tidak melebihi dari ancaman maksimum pidana pokoknya sesuai dengan ketentuan dalam Undang-Undang lamanya pidana tersebut telah ditentukan dalam putusan pengadilan. (Pasal 18 ayat (1) huruf b, ayat (2), (3) UndangUndang Nomor 31 Tahun 1999). Ketika suatu pembayaran pengembalian kerugian keuangan negara telah dibayarkn seluruhnya tapi hal tersebut tidak menghapuskan dipidananya pelaku tindak pidana tersebut (Pasal 4);

c. Pidana denda dimana merupakan pidana pokok dari tindak pidana korupsi memiliki aspek Undang-Undang Pemberantasan Tindak Pidana Korupsi yaitu dapat disebut pula pidana pokok metode komulatif-alternatif;

d. Penetapan perampasan barang-barang bukti yang telah disita dalam hal terdakwa meninggal dunia sebelum putusan dijatuhkan bukti yang cukup kuat bahwa pelaku telah melakukan tindak pidana. (Pasal 38 Undang-Undang Nomor 20 Tahun 2001 tentang Perubahan Atas UndangUndang No. 31 Tahun 1999);

e. Putusan terkait perampasan harta kekayaan guna dilelang untuk mengembalikan kerugian negara dalam hal terdakwa tidak dapat membuktikan bahwa harta benda tersebut diperoleh bukan dari tindak pidana korupsi. (Pasal 38 UU Nomor 20 tahun 2001 tentang perubahan atas UU No. 31 tahun 1999).

Mekanisme pembayaran pengganti kerugian negara menurut penulis masih belum terperinci dan jelas dalam mengatur pembayaran pengganti kerugian negara karena dengan contoh 2 (dua) kasus yaitu Putusan No. 2471 K/Pid/2006 dan Putusan No. 
$682 \mathrm{~K} / \mathrm{PID} / 2004$, kedua putusan tersebut mengadili terdakwa dengan pidana tambahan pembayaran pengganti kerugian negara namun pengembalian uang sejumlah itu tidak secara nyata dengan jumlah yang sama melainkan barang-barang yang telah dihitung dan disita sejumlah kerugian tersebut dilelang guna menutupi kerugian negara. Pada Pasal 18 Undang-Undang Nomor 31 Tahun 1999 dengan PERMA Nomor 5 Tahun 2015 juga tidak ada proses mekanisme secara rinci pembayaran kerugian tetapi lebih menjelaskan mengenai perampasan penyitaan lalu dilelang guna menutupi kerugian negara, bahkan tidak ada pula aturan lama pidana pengganti kurungan bila pidana tambahan pembayaran kerugiann keuangan negara tidak dapat dipenuhi.

Hakim sebagai pemegang kekuasaan dalam persidangan dapat mengadili terdakwa mengenai proses pembayaran penganti kerugian atau penyitaan lalu dilelang guna menutupi kerugian negara. Bila memang pidana tambahan atau aset dari terpidana tidak memenuhi maka terpidana diberikan pidana pengganti berupa penjara. Penjatuhan pidana tambahan atau pidana pengganti pidana tambahan tersebut adalah waewenang hakim yang mengacu pada tuntutan oleh jaksa penuntut umum sebagai arah melakukan kebijakan dalam penjatuhan putusan yang dilakukan oleh hakim. Dalam putusan tindak pidana korupsi pembayaran pengganti kerugian sebagai pidana tambahan yang harus dipenuhi oleh terpidana.

Kewenangan Jaksa Sebagai Instansi Selain BPK Untuk Menentukan Penghitungan Jumlah Kerugian Keuangan Negara.

Mencermati kedudukan Kejaksaan RI dalam kedudukan sentralnya sehubungan dengan penegakkan hukum di Indonesia maka keberadaan Kejaksaan RI sebagai salah satu subsistem dari suatu sistem hukum. R. Subekti menjelaskan terkait sistem hukum yaitu suatu susunan yang teratur, kesuluruhan yang terdiri atas bagian-bagian yang saling berkaitan satu sama lain, hasil dari suatu pemikiran, guna mencapai tujuan. Hal terpenting bagi suatu proses sistem adalah keseimbangan potensi dan fungsi masing-masing kompenennya.

Untuk itu idealnya juga kedudukan dan fungsi Kejaksaan RI diatur dengan tegas dalam UUD 1945 dalam Undang-Undang yang mengatur keberadaan Kejaksaan, termasuk siapa yang memilih, mengangkat, menetapkan, dan mengesahkannya, bagaimana prosedur/mekanisme pemilihan, pengangkatan, penetapan, pengesahannya dan pertanggung jawaban atas tugas dan kewajibannya.

Kejaksaan merupakan pengendali proses perkara pidana karena mempunyai posisi/kedudukan sentral dalam penegakkan hukum, karena hanya institusi Kejaksaan yang dapat menentukan apakah suatu kasus dapat diajukan ke Pengadilan atau tidak berdasarkan alat bukti yang sah sebagaimana menurut hukum acara pidana. Ditegaskan dalam Pasal 30 UU Kejaksaan Republik Indonesia, Kejaksaan memiliki tugas dan wewenang di bidang pidana ialah:

a. Melakukan penuntutan;

b. Melaksanakan penetapan hakim dan putusan pengadilan yang telah memperoleh kekuatan hukum tetap;

c. Melakukan pengawasan terhadap pelaksanaan putusan pidana bersyarat, putusan pidana pengawasan, dan keputusan lepas bersyarat;

d. Melakukan penyidikan tindak pidana berdasarkan $\mathrm{UU}$;

e. Melengkapi berkas suatu perkara dan dapat melakukan pemeriksaan tambahan sebelum dilimpahkan ke pengadilan yang dalam pelaksanaannya dikoordinasikan dengan penyidik.

Dalam Penjelasan Pasal 30 Undang-Undang Kejaksaan RI dapat diambil suatu kesimpulan bahwa pelaksanaan tugas dan wewenang Kejaksaan membina hubungan kerjasama dengan badan-badan penegak hukum dan keadilan oleh badan negara.

Kejaksaan mempunyai tugas dan wewenang dalam melakukan penyidikan terhadap tindak pidana tertentu. Tindak pidana tertentu menurut UndangUndang adalah dijelaskan dalam penjelasan Pasal 30 ayat (1) huruf d Undang-Undang Kejaksaan RI bahwa kewenangan dalam ketentuan ini adalah kewenangan sebagaimana diatur misalnya dalam Undang-Undang Nomor 26 Tahun 2000 tentang Pengadilan Hak Asasi Manusia dan Undang-Undang Pemberantasan Tindak Pidana Koruspi sebagaimana yang telah dirubah menjadi Undang-Undang Komisi Pemberantasan Korupsi.

Kejaksaan merupakan lembaga yang berwenang melakukan penyidikan dalam hal tindak pidana korupsi, Kejaksaan bertugas melakukan pencarian bukti-bukti dan tersangka tindak pidana korupsi. Bila 
Novian Ardynata Setya Pradana, Arif Satria Subekti, dan Cahyo Harjo Prakoso,

Kewenangan Lembaga Hukum Dalam Menentukan Besaran Kerugian dan Pengembalian Keuangan Negara Hasil Tindak Pidana Korupsi

dikaitkan dengan kerugian keuangan negara maka bukti-bukti tersebut harus sesuai dan terbukti adanya kerugian yang timbul terhadap keuangan negara. ${ }^{13}$

Alat bukti memang merupakan hal yang sangat penting bagi seorang jaksa dalam mengungkap atau meneruskan suatu kasus tindak pidana korupsi ke tahap penuntutan di Pengadilan, tapi bukan berarti kejaksaan dapat menghitung kerugian keuangan negara, karena sudah sangat jelas bahwa yang berhak untuk menghitung kerugian keuangan negara adalah BPK, kejaksaan hanya berhak untuk melakukan penyidikan tindak pidana korupsi dan menuangkan angka kerugian keuangan negara sebagai alat bukti harus didasarkan pada Laporan Hasil Pemeriksaan Audit oleh BPK.

Perhitungan kerugian keuangan negara merupakan hal yang sangat sulit untuk menghitungnya, diperlukan pengetahuan yang khusus untuk memperlajari cara menghitung kerugian keuangan negara ini, maka dari itu sebenarnya undang-undang telah menyatakan bahwa BPK-lah yang berhak mengaudit kerugian keuangan negara ini, karena BPK tentu sudah dibekali dengan ilmu khusus yang meperlajari perhitungan kerugian keuangan negara ini, agar mendapatkan hasil yang tepat, pasti dan akurat. Sedangkan jaksa dalam posisi ini tentu bukan merupakan ahli dalam perhitungan kerugian keuangan negara, Jaksa hanya menghitung kerugian keuangan negara yang sudah pasti dan nyata telah terjadi kerugian tersebut. Dalam SEMA No. 4 Tahun 2006 telah menyatakan: "Instansi yang berwenang menyatakan ada tidaknya kerugian keuangan negara adalah Badan Pemeriksa Keuangan yang memiliki kewenangan konstitusional, sedangkan instansi lainnya seperti BPKP/Inspektorat/Satuan Kerja Perangkat Daerah tetap berwenang melakukan pemeriksaan dan audit pengelolaan keuangan negara. Namun, tidak berwenang menyatakan atau mendeclare adanya kerugian keuangan negara."

Hakim dalam memutuskan suatu perkara memiliki kewenangan atau disperitas hakim guna mengambil suatu kebijakan yang di atur dalam Pasal 5 ayat (1) Undang-Undang Nomor 48 Tahun 2009 tentang Kekuasaan Kehakiman, pada pasal tersebut menerangkan bahwa hakim wajib menggali,

\footnotetext{
13 Marwan Effendy. (2005). Kejaksaan RI Posisi dan Fungsinya Dari Prespektif Hukum. Jakarta: Gramedia Pustaka Utama, h. 138.
}

mengikuti dan memahami nilai-nilaia hukumn dan rasa keadilan, maka harusnya hakim mengikuti aspekaspek yang ada di dalam Undang-Undang Kekuasaan Kehakiman tersebut. Penulis berpendapat bahwa kewenangan hakim dalam memutus suatu perkara harus memenuhi norma dan keadilan tersebut dapat merubah tuntutan yang telah disusun oleh penuntut umum, hakim mempertimbangkan segala aspek demi menjunjung tinggi keadilan tersebut dapat merubah sesuai pendapat hakim itu sendiri.

Ratio Decidendi yang muncul juga dipertimbangkan harus dengan rasa kemanusiaan dan keadilan yang tinggi. Ratio Decidendi atau yang biasa disebut sebagai pertimbangan hakim merupakan alasan-alasan yang digunakan oleh hakim sebagai pertimbangan hukum sebelum memutus perkara yang didasarkan oleh fakta-fakta materi. ${ }^{14}$ Hakim melihat pada fakta-fakta yang ada yang sesuai dengan buktibukti yang ada secara nyata telah ditemukan. Maka dari itu seharusnya judex facti ini tidak menerima perhitungan kerugian keuangan negara yang dihitung dari hasil Jaksa/Penunut Umum dan bukan dihitung oleh BPK lembaga yang khusus ditunjuk untuk menghitung kerugian keuangan negara, sehingga seharusnya tidak dapat dipakai untuk menjadi alat bukti dalam penentuan kerugian keuangan negara sebagaimana yang didakwakan terhadap terdakwa. Pertimbangan hakim dalam penghitungan kerugian keruangan negara tersebut harus satu atap dengan hitungan tuntutan jaksa karena bila memang satu atap pedomannya misal dari BPK, hal ini akan mempermudah untuk memutuskan karena hitungannya sudah tetap dan bila ada hitungan yang keliru maka metoda penghitungannya akan sama dan hasil yang ditemukan akan konkrit.

\section{PENUTUP}

\section{Kesimpulan}

Pengawasan dan perhitungan mengenai kerugian keuangan negara dilakuan oleh beberapa lembaga yaitu KPK sesuai dengan Pasal 7 Undang-Undang Nomor 30 Tahun 20002 membahas mengenai kewenangan tersebut, BPKP sesuai dengan Pasal 2 Keppres Nomor 31 Tahun 1983 yang membahas mengenai tugas tersebut dan lembaga terakhir yang berwenang adalah BPK sesuai dengan Pasal

\footnotetext{
${ }^{14}$ I.P.M Ranuhandoko. (2003). Terminologi Hukum InggrisIndonesia. Cetakan ketiga. Jakarta: Sinar Grafika, h. 475
} 
3 ayat (1) Undang-Undang Nomor 15 Tahun 2006 membahas bahwa BPK memiliki kewenangan untuk mengaudit kerugian keuangan negara. Jaksa selaku penyidik berwenang untuk mengumpulkan alat bukti yang dapat mengkuatkan tuntutan terhadap terdakwa menerapkan Pasal 30 Undang-Undang Kejaksaan RI jaksa memiliki wewenang untuk membina hubungan kerja sama dengan badan-badan penegak hukum dan keadilan badan negara dan juga instansi lainnya yang bersangkutan. Pada kasus tindak pidana korupsi jaksa dalam mengumpulkan alat bukti harus bekerja sama dengan instansi yang diatur sesuai undang-undang yang berlaku, karena menghitung juga merupakan bagian dari wewenang kejaksaan untuk membuktikan bahwa benar adanya kerugian keuangan negara hasil tindak pidana korupsi. Aturan pidana tambahan pembayaran uang pengganti bukanlah pidana pokok maka terpidana lebih memilih pidana penjara dari pada membayar kerugian negara. Mekanisme pembayaran pengganti kerugian keuangan negara tidak diatur pada Pasal 18 ayat (1) huruf $b$ dengan diperlengkapi PERMA Nomor 5 Tahun 2014. Pembayaran pengganti kerugian keuangan negara tidak menghapuskan pidana pokoknya, pembayaran dapat dilakukan setelah tuntutan hingga 1 bulan setelah putusan berkekuatan hukum tetap.

\section{Rekomendasi}

Perlu adanya aturan penguat terkait pembayaran pidana tambahan pembayaran uang pengganti, karena dianggap perlu agar negara tidak merugi akan jumlah kerugian keuangan negara tersebut. Hal ini memberikan payung hukum yang pasti dan tidak tumpang tindih antara kewenangan satu dengan yang lainnya. Sinkronisasi peraturan UU yang telah dilakukan haruslah sesuai dengan praktek. maka perlu adanya pengawasan yang terkoordinasi terkait kewenangan-kewenangan dalam menghitung kerugian keuangan negara.

\section{DAFTAR PUSTAKA}

\section{Peraturan Perundang-undangan:}

Undang-Undang Dasar Republik Indonesia Tahun 1945.

Undang-Undang Nomor 28 Tahun 1999 tentang Penyelenggaraan Negara yang Bersih dan Bebas dari Korupsi, Kolusi, dan Nepotisme.
Undang-Undang Nomor 31 Tahun 1999 jo. Undang-Undang Nomor 20 Tahun 2001 tentang Pemberantasan Tindak Pidana Korupsi.

Undang-Undang Nomor 15 Tahun 2006 tentang Badan Pemeriksa Keuangan.

Kitab Undang-Undang Hukum Pidana (KUHP).

Peraturan Mahkamah Agung Republik Indonesia Nomor 5 Tahun 2014 tentang Pidana Tambahan Uang Pengganti Dalam Tindak Pidana Korupsi.

TAP MPR-RI Nomor XI/MPR/1989 tentang Penyelenggaraan Negara Yang Bersih dan Bebas KKN.

Peraturan Pemerintah Nomor 65 Tahun 1999 tentang Tata Cara Pemeriksaan Kekayaan Penyelenggara Negara.

Peraturan Penguasa Militer No. PRT/PM/06/1957 tentang Pemberantasan Korupsi.

Putusan Mahkamah Agung RI No. 934 K/Pid/1999 Tanggal 28 Agustus 2000.

\section{Buku:}

Bohari. (1992). Pengawasan Keuangan Negara. Jakarta: Rajawali.

Ermansjah Djaja. (2008). Memberantas Korupsi Bersama KPK. Jakarta: Sinar Grafika.

I.P.M Ranuhandoko. (2003). Terminologi Hukum Inggris-Indonesia. Cetakan Ketiga. Jakarta: Sinar Grafika.

M. Yahya Harahap. (2012). Pembahasan Permasalahan dan Penerapan KUHAP, Penyidikan dan Penuntutan. Edisi Kedua. Jakarta: Sinar Grafika.

Marwan Effendy. (2005). Kejaksaan RI Posisi dan Fungsinya Dari Prespektif Hukum. Jakarta: Gramedia Pustaka Utama.

P.A.F Lamintang dan Theo Lamintang. (2009). Delik-Delik Khusus Kejahatan Jabatan dan Kejahatan Jabatan Tertentu Sebagai Tindak Pidana Kourpsi. Jakarta: Sinar Grafika.

Peter Mahmud Marzuki. (2005). Penelitian Hukum. Edisi Pertama. Cet. VII. Jakarta: Kencana.

Purwaning M. Yanuar. (2007). Pengembalian Aset Hasil Korupsi. Bandung: Alumni.

Romli Atmasasmita. (2002). Korupsi, Good Governance dan Komisi Anti Korupsi di Indonesia. Jakarta: Badan Pembinaan Hukum Nasional Departemen Kehakiman dan HAM RI. 
Novian Ardynata Setya Pradana, Arif Satria Subekti, dan Cahyo Harjo Prakoso,

Kewenangan Lembaga Hukum Dalam Menentukan Besaran Kerugian dan Pengembalian Keuangan Negara Hasil Tindak Pidana Korupsi

Soetrisno. (1982). Dasar-Dasar Ilmu Keuangan

Negara. Yogyakarta: Fakultas Ekonomi Universitas Gadjah Mada.

W.J.S Poerwadarminta. (1976). Kamus Umum Bahasa Indonesia. Jakarta: Balai Pustaka.
Jurnal:

Budi Hariyanto. (2018). "Penerapan Pidana Uang pengganti Kepada Korporasi Dalam Perkara Korupsi Demi Pemulihan Kerugian Keuangan Negara". Jurnal RECHTSVINDING Media Pembinaan Hukum Nasional. Volume 7 Nomor 1 Tahun 2018.

Nur Basuki Minarno. (2007). "Pembuktian Unsur Penyalahgunaan Wewenang Dalam Tindak Pidana Korupsi”. Jurnal Perspektif. 12(1), h. 54-55. 